Original Research Paper

\title{
Pembelajaran Tentang Pemanfaatan Sampah Organik Rumah Tangga Sebagai Bahan Baku Eko-Enzim
}

\author{
Lolita Endang Susilowati ${ }^{1 *}$; Mansur Ma'Shum ${ }^{1}$; Zaenal Arifin ${ }^{1}$ \\ ${ }^{1}$ Jurusan Ilmu Tanah, Fekultas Pertanian, Universitas Mataram, Mataram, Indonesia
}

https://doi.org/10.29303/jpmpi.v3i2.1147

Sitasi: Susilowati, L. E., Ma'Shun, M \& Arifin, Z. (2021). Pemberdayaan Ekonomi Nelayan Rajungan Melalui Pengembangan Teknologi Alat Tangkap Bubu fi Desa Pemongkong Kabupaten Lombok Timur. Jurnal Pengabdian Magister Pendidikan IPA 4(4)

\author{
Article history \\ Received: 02 Oktober 2021 \\ Revised: 20 Oktober 2021 \\ Accepted: 09 November 2021 \\ *Corresponding Author: \\ Lolita Endang Susilowati, \\ Jurusan Ilmu Tanah, Fekultas \\ Pertanian, Universitas \\ Mataram, Mataram, Indonesia \\ Email: \\ lolitaabas37@unram.ac.id
}

\begin{abstract}
Persoalaan sampah rumah tangga, khususnya jenis sampah organic, masih menjadi issue yang mengemuka yang membutuhkan penyelesaian. Kebanyakan masyarakat masih menerapkan pola pengelolaan sampah konvensional yaitu menimbun sampah organic di suatu tempat/lokasi. Timbulan sampah ini berpotensi memunculkan masalah baru, seperti terjadi emisi gas metana $\left(\mathrm{CH}_{4}\right)$, timbulnya bau yang tidak sedap, air lindi sampah berpotensi mencemari lingkungan. Karena itu kepada masyarakat perlu diberikan pembelajaran mengenai cara penanganan sampah organic untuk mengurangi jumlah sampah organic yang ditimbun di tempat pembuangan sampah. Salah satu caranya yaitu dengan memanfaatkan limbah organik segar, limbah buah dan/atau sayur, menjadi produk Eko-Ensim. Filtrat dari Eko-Ensim digunakan sebagai pupuk organic cair dan/atau pestisida nabati, sedangkan padatannya digunakan sebagai pupuk organic padat. Kegiatan ini dilaksanakan bermitra dengan Kelompok Pemanfaat Sampah "PaManSam" yang berlokasi di Desa Narmada Kecamatan Narmada Kabupaten Lombok Barat- NTB. Sebagai sasaran pembelajaran adalah petani milinial dan mahasiswa PKL di kelompok PaManSam. Kegiatan ini diawali dengan sosialisasi mengenai UU RI no 18 tahun 2008 dan Peraturan Daerah Provinsi Nusa Tenggara Barat Nomor 5 Tahun 2019 tentang Pengelolaan Sampah. Kegiatan kedua adalah Bimtek Pembuatan Eko-Ensim, diawali dengan persiapan bahan, pelaksanaan fermentasi Eko-Ensim, analisis karakteristik filtrat Eko-Ensim. Hasil kegiatan sebagai berikut, peserta kegiatan 1) memiliki pengetahuan tentang pengelolaan sampah menurut UU dan Peraturan Daerah yang berlaku; 2) menguasai teknik pembuatan Eko-Ensim; 3) Eko-Ensim yang dihasilkan ber-pH netral. Teknik pembuatan Eko- Ensim ini dapat diaplikasikan untuk membuatan produk lain dengan berbahan baku bahan organic segar.
\end{abstract}

Kata Kunci: Pengelolaan sampah, Eko-Ensim, Pupuk Organic Cair

\section{Pendahuluan}

Permasalahan timbunan sampah rumah tangga di lingkungan rumah tangga masih saja menjadi isu besar yang memerlukan penanganan. Pada umumnya, kesadaran masyarakat untuk pengelolaan sampah masih tergolong rendah. Kebanyakan dari mereka, dalam mengelola sampah masih menerapkan pola tradisonal yaitu sampah dikumpulkan, diangkut, dan dibuang ke tempat pemrosesan akhir sampah. Sementara, timbunan sampah dengan volume besar di lokasi tempat pemrosesan akhir sampah berpotensi memunculkan masalah baru, seperti terjadi emisi gas rumah kaca, gas metan $\left(\mathrm{CH}_{4}\right)$, yang bersumber dari proses pembusukan anaerobic, memunculkan bau yang 
tidak sedap, air lindi sampah berpotensi sebagai bahan pencemar lingkungan.

Upaya untuk mengurangi timbunan sampah di tempat pembuangan akhir (TPA) harus diawali dengan mengelola sampah mulai dari lokasi asal sumber sampah. Menurut UU no 18 Tahun 2008 didefinisikan pengelolaan sampah adalah kegiatan yang sistematis, menyeluruh, dan berkesinambungan yang meliputi pengurangan dan penanganan sampah. Upaya yang dapat ditempuh dalam tujuan pengelolaan sampah adalah mengubah sampah menjadi material yang memiliki nilai ekonomis dan tidak membahayakan bagi lingkungan. Karenanya, mengurangi timbunan dari sumbernya dengan cara mengubah sampah menjadi material yang mempunyai nilai ekonomi merupakan suatu keniscayaan (Putri, 2018).

Volume sampah organik yang dihasilkan oleh kegiatan rumah tangga cukup besar volumenya, mencapai $60-70 \%$ dari total sampah yang dihasilkan (Susilowati et al., 2021), meliputi sisa makanan, kulit buah, sisa sayuran dan limbah hewani. Semua bahan tersebut dapat diolah menjadi menjadi pupuk organic berkualitas menjadi pupuk organic berkualitas. Hanya saja tidak semua sampah organic tersebut dapat menjadi bahan baku pupuk organic cair. Sampah organik yang dapat dijadikan sebagai bahan baku pupuk cair adalah, sisa buah, kulit buah dan sisa sayuran. Mengelola sebagian sampah organik menjadi pupuk cair organic tidak saja mengurangi timbunan sampah, tetapi juga dapat menjadi sumber pendapatan keluarga baik secara langsung atau tidak langsung (Moerad, 2012) . Peningkatan pendapatan keluarga secara langsung diperoleh dari penjualan pupuk organic cair yang dihasilkannya, sedangkan secara tidak langsung dapat melalui pemanfatannya sebagai pupuk organic pada tanaman sayuran yang dibudidaakan di halaman rumah.

Proses pembuatan pupuk organic cair dapat dibuat dengan memfermentasi sampah organik. Teknik fermentasi sampah sisa sayur, kulit buah dan sisa buah organic dengan waktu fermentasi minimal tiga bulan dikenal dengan istilah pembuatan Eko-Ensim (Dewi, 2021). Produk EkoEnsim adalah cairan yang mengandung sejumlah enzim seperti Lipase, Tripsin, Amilase, asam organic seperti Asam Asetat $\left(\mathrm{H}_{3} \mathrm{COOH}\right)$, dan sejumlah mineral hara tanaman seperti N,P dan $\mathrm{K}$ (Larasati et al., 2020). Dari sisi lingkungan pembuatan Eko-Ensim memberikan keuntungan tersendiri karena selama proses fermentasi berlangsung dihasilkan gas $\mathrm{O}_{3}$ (Yanti et al., 2021). Cairan Eko-Ensim selain mengandung hara tanaman juga mengandung bakteri yang berpotensi sebagai perombak bahan organic, perangsang pertumbuhan dan sebagai agens pengendali hama dan penyakit tanaman (Utami et al., 2020). Di bidang pertanian, cairan Eko-Ensim dapat dimanfaatkan sebagai pupuk organik cair, amelioran tanah dan pengendali hayati organisme penggagu tanaman....

Cairan Eko-Ensim dengan fungsi yang multiguna, dan dengan proses pembuatan yang sangat sederhana serta bahan baku tersedia di sekitar lingkungan kita menjadi pilihan yang tepat untuk mengolah limbah organic sayur dan buah. Karakteristik kimia dari cairan Eko-Ensim ditentukan oleh jenis dan komposisi bahan baku (Astuti \& Maharani, 2020). Pembuatan Eko-Ensim ini dapat dikembangkan untuk menghasil produk lain dengan berbasiskan pada proses fermentasi bagian tanaman yang mudah terdekomposisi, seperti dalam pembuatan hansanitiser-nabati, farfum-nabati. Karena itu, teknik pembuatan EkoEnsim perlu diintroduksi ke masyarakat sebagai bagian dari teknik pengelolaan sampah sebagaimana yang diatur dalam UU RI no 18 tahun 2008, BAB IV Paragraf Kesatu Pasal 20 dan Paragraf Kedua Pasal 22.

Kegiatan ini bertujuan (1) memberikan pengetahuan masyarakat mengenai cara pengelolaan sampah rumah tangga menurut UU RI no 18 Tahun 2008 tentang Pengelolaan Sampah; (2) Memberikan bimbingan teknik pembuatan EkoEnsim untuk menghasilkan pupuk organic cair yang berkualitas. Kedepan, kegiatan ini diharapkan mampu mengedukasi masyarakat dalam mengelola sampah menjadi produk yang ramah lingkungan dan memiliki nilai ekonomi. Melalui kegiatan ini juga diharapkan masyarakat semakin kreatif dan inovatif dalam mengolah sampah/limbah organik yang ramah lingkungan.

\section{Metode}

Kegiatan pengabdian ini dilaksanakan dalam kurun waktu 6 bulan, mulai April sd Oktober 2021. Kegiatan ini bermitra dengan kelompok pengelola dan pemanfaat sampah "PaManSam" yang berlokasi di Desa Narmada kecamatan Narmada 
kabupaten Lombok Barat- NTB. Metode pendekatan yang digunakan adalah partisipatif, melibatkan mitra dan kelompok sasaran (petani millenial dari kelompok PaManSam dan mahasiswa PKL), mulai dari proses perencanaan kegiatan, pelaksanaan sampai dengan monitoring dan evaluasi kegiatan. Bentuk kegiatan meliputi penyuluhan dan bimbingan teknologi pembuatan Eko-Ensim untuk menghasilkan pupuk organic. Tahapan kegiatan pengabdian ini meliputi: (1) persiapan kegiatan, (2) pelaksanaan penyuluhan dan praktik langsung, (3) evaluasi kegiatan.

\section{Persiapan Kegiatan}

Tim pelaksana pengabdian dengan petani millenial dari kelompok PaManSam melaksanakan FGD. Tujuan FGD adalah membangun kesepakatan Bersama terkait dengan tugas dan tanggung jawab masing-masing pihak. Pada kegiatan ini tim pengabdian disepakati sebagai nara sumber, dan mitra sasaran berkontribusi atas sarana yang diperlukan pada kegiatan pengabdian ini. Disamping itu disepakati juga jadwal pelaksanaan kegiatan selama kegiatan berlangsung.

\section{Pelaksanaan Kegiatan}

$>$ Penyuluhan. Materi penyuluhan tentang pengelolaan sampah dengan merujuk pada UU no 18 tahun 2008 tentang Pengelolaan sampah dan Peraturan Daerah Provinsi Nusa Tenggara Barat nomor 5 tahun 2019 tentang Pengelolaan Sampah

> Praktik Pembuatan Eko-Ensim dan pemanfaatannya sebagai pupuk organic Cair

Kegiatan bimtek pembuatan Eko-Ensim dan aplikasinya sebagai pupuk organic cair

\section{Evaluasi kegiatan}

Evaluasi kegiatan dilakukan bersama mitra terkait dengan pencapaian tujuan kegiatan yang telah disepakati bersama. Evaluasi kegiatan dilakukan dengan melihat respon peserta selama kegiatan berlangsung dan nilai peserta atas kuisioner yang harus dijawab.

\section{Hasil dan Pembahasan}

\section{Penyuluhan UU RI no 18 Tahun 2018}

Sebagai kegiatan pertama dari kegiatan ini adalah penyuluhan UU RI no 18 Tahun 2008 dan Perda Provinsi NTB no 5 Tahun 2019 tentang
Pengelolaan Sampah. Pada kegiatan ini, peserta penyuluhan menunjukkan antusias dan semangatnya dalam mengikuti acara sosialisi tentang UU pengelolaan sampah. Hal ini ditunjukman dengan ragam pertanyaan yang diajukan oleh peserta penyuluhan mulai dari apa aitu sampah sampai dengan pertanyaan yang terkait dengan pola pengelolaan sampah yang efisien dan efektif. Beberapa gambar terkait dengan pelaksanaan penyuluhan ditunjukkan dalam Gambar 1.

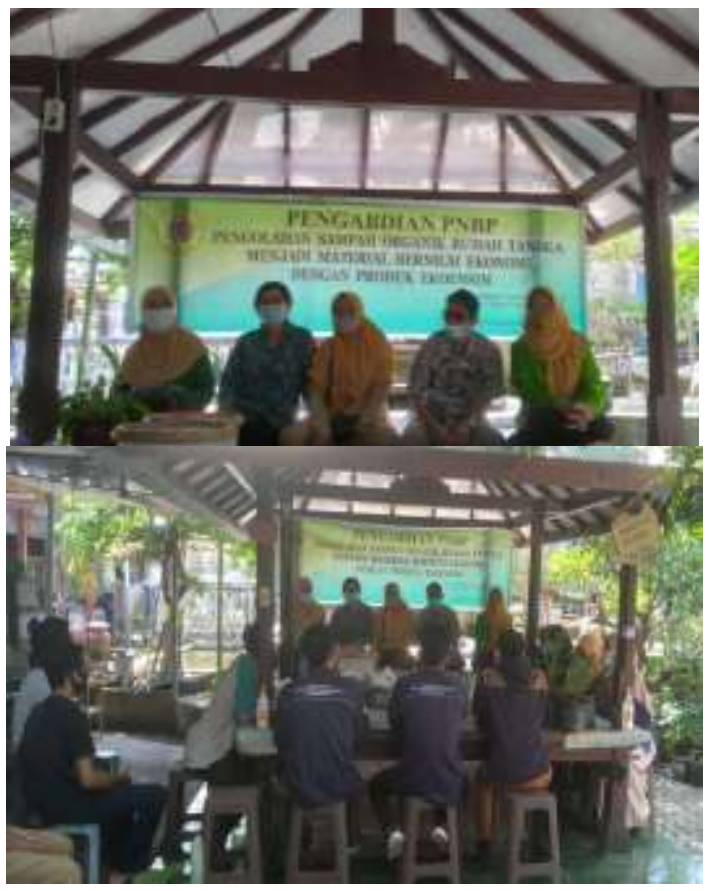

Gambar 1. Penyuluhan Tentang Pengelolaan Sampah

Menurut UU RI No.18 Tahun 2008 tentang Pengelolaan Sampah, pasal 1 ayat 1 sampah adalah sisa aktivitas sehari-hari manusia dan atau sisa dari proses alam yang berbentuk padat. Pasal 1 ayat 4 berbunyi Penghasil sampah adalah setiap orang dan/atau akibat proses alam yang menghasilkan timbulan sampah. Pasal 1 ayat 5, pengelolaan sampah adalah kegiatan yang sistematis, menyeluruh, dan berkesinambungan yang meliputi pengurangan dan penanganan sampah. Pengelolaan sampah di tingkat sumber dilakukan dengan memilah sampah sesuai dengan golongannya, anorganik dan organic (plastic dan lainnya), pewadahan sampah sesuai golongannya dan penanganan sampah sesuai dengan golongannnya. 
Di tengah masyarakat, teknik pengolahan sampah dilakukan dengan menerapkan pola pengelolaan sampah $3 \mathrm{R}$. R ke satu adalah reduksi sampah untuk pembatasan timbulan sampah, diantaranya dengan meningkatkan masa umur penggunaan suatu produk, merubah sampah menjadi produk bernilai ekonomi, mengurangi jumlah bahan yang digunakan $\mathrm{R}$ kedua adalah pemanfaatan kembali barang yang sudah tidak digunakan sebagaimana mestinya. Contoh plastic bekas minyak goreng dan kertas bekas wadah semen digunakan Kembali sebagai pot tanam terong (Gambar 2).

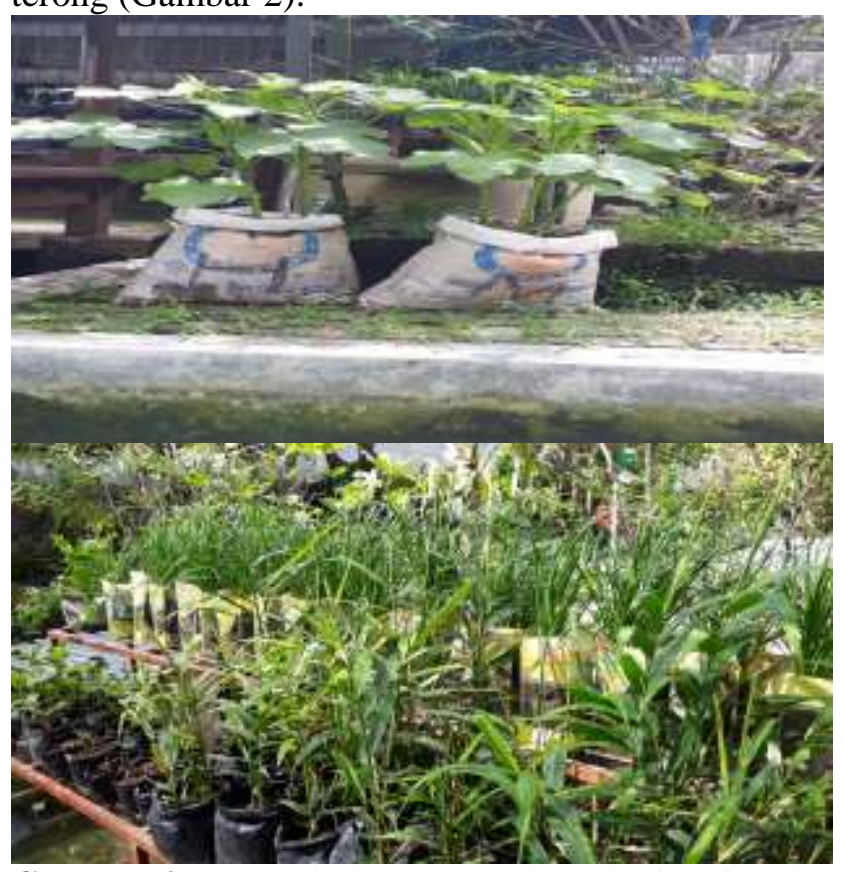

Gambar 2. Kertas bekas semen dan plastic minyak digunakan sebagai pot tanaman.

R ketiga adalah recycle atau daur ulang sampah yangmana kegiatan daur ulang sampah ini umumnya ditujukan untuk penanganan sampah anorganik. Kegiatan daur ulang ini diawali dengan memilah-milah sampah plastic dari sumbernya. Contoh, material sampah plastic yang dapat dimanfaatkan sebagai bahan kerajinan tangan dikumpulkan dalam satu wadah tersendiri, demikian juga dengan botol plastic dan sampah anorganik lainnya. Pendaur ulangan sampah botol minuman secara efektif hanya dapat berlangsung melalui proses industry. Dalam hal ini bank sampah mempunyai peran untuk memenuhi kebutuhan botol plastic dalam jumlah besar (skala industry). Bank sampah sudah mulai dimasyarakatkan hanya saja belum berfungsi secara optimal. Peran masyarakat peduli sampah seharusnya segera menjadi nasabah banksampah, karena dengan menjadi nasabah berarti telah berkontribusi dalam mengurangi timbunan sampah anorganik.

Terkait dengan pengolahan sampah organic, sampah ini dapat dimanfaatkan sebagai bahan baku produk arang atau kompos/pupuk organic untuk tanaman. Pengolahan sampah organic menjadi produk pupuk organic merupakan cara yang mudah dalam pengerjaannya. Proses pembuatan pupuk organic dapat dilakukan dengan pengomposan secara aerobic dan anaerobic (Nur et al., 2016) atau dengan metode Eko Ensim (Yanti et al., 2021). Proses pembuatan kompos (pupuk organic) secara erobik dikerjakan di tempat terbuka dan untuk mempercepat proses pembusukannya perlu dihadirkan decomposer aerobic. Proses pembuatan secara anarganik tidak membutuhkan adaya sirkulasi udara, karena proses anaerobic tidak membutuhkan oksigen. Proses anaoerobik memerlukan kehadiran pendekomosisi bahan organic anaerobic. Proses ekoensim pada prinsipnya adalah sama dengan pengomposan anaerobik (fermentasi) hanya saja bahan bakunya adalah sampah organic yang belum mengalami pembusukan.

Setelah penyampaian materi oleh nara sumber, sesi berikutnya adalah tanya jawab dan diskusi. Ada beberapa pertanyaan yang diajukan oleh peserta untuk didiskusikan bersama, dintaranya (1) jenis bahan baku kompos/pupuk organic yang dapat menghasilkan pupuk organic yang berkualitas, (2) kualitas kompos yang dibuat secara aerob atau anaerob yang akan menghasilkan pupuk organic yang berkulitas.baik (3) bagaimana menghilangkan mau kompos yang seringkali memunculkan bau yang tidak sedap. Pertanyaan dibahas dengan baik oleh peserta dan didampingi oleh naras umber. Hasil diskusi menjadikan peserta puas, karena memiliki pengetahuan yang lebih koperhensif tentang pengelolaan sampah sesuai dengan peraturan yang berlaku.

Dengan dilakukannya penyuluhan tentang pengelolaan sampah sebagaimana diatur dalam UU RI no 8 tahun 2008, 
diharapkan dapat membangun kesadaran masyarakat untuk lebih peduli terhadap upaya minimalisasi timbulan sampah.

\section{Kegiatan Bimtek Eko-Ensim}

Keistimewaan pembuatan pupuk organic cair dengan teknologi Eko-Enzim adalah untuk proses pembuatannya tidak memerlukan lahan yang luas seperti pada proses pembuatan kompos. Proses pembuatannyapun sangat mudah dan perangkat yang dibutuhkan sangat sederhana, yaitu pisau untuk memotongmotong sampah organic, dan wadah fermentasi dari bahan plastic. Karena itu dapat dipastikan bahwa anggota keluarga dapat membuatnya. Ditinjau dari prosesnya, pembuatan Eko-Ensim memberikan keuntungan tersendiri terhadap lingkungan atmosfer, karena selama proses fermentasi akan dihasilkan gas O3 (ozon) yang terbebas ke atmosfir dan berguna untuk menyerap radiasi cahaya ultraviolet yang berbahaya bagi kesehatan manusia, hewan daan tumbuhan. Reaksi pembentukan ozon selama proses fermentasi adalah sebagai berikut:

$$
\mathrm{CO} 2+\mathrm{N} 2 \mathrm{O}+\mathrm{O} 2 \rightarrow \mathrm{O} 3+\mathrm{NO} 3+\mathrm{CO} 3
$$

Pada tahap peksanaan bimtek pembuatan EkoEnsim, kepada peserta diberikan penjelasan oleh narasumber mengenai pengertian Eko-ensim, prinsip dasar proses pembuatan dan manfaat EkoEnsim. Istilah Eko-Ensim pertama kali dikenalkan oleh Dr Joean Oon yang pada prinsipnya merupakan proses fermentasi sampah organic sisa sayuran, kulit buah dan sisa buah yang masih belum mengalami pembusukan. Proses fermentasi pada pembuatan Eko-Ensim minimal membutuhkan waktu 3 bulan. Dengan demikian pembebasan ensim dan senyawa organic lainnya yang terdapat dalam bahan baku ke lingkungan fermentor berlangsung secara optimal.

Cairan Eko-Ensim dengan fermentasi sempurna memiliki tingkat kemasaman tinggi. Hasil praktek pembuatan ekoensim dengan bahan baku limbah papaya, nenas dan kulit pisang setelah 3 bulan waktu fermentasi menunjukkan $\mathrm{pH}$ 4. Cairan Eko-Ensim selain mengandung sejumlah sejumlah ragam ensim (tergantung pada bahan bakunya) mengandung juga senyawa alhokol, asam asetat dan sejumlah mineral seperti
N, P dan K. Bahan yang diperlukan untuk pembuatan Eko-Ensim, selain bahan baku yang akan difermentasi diperlukan juga gula merah yangmana gula merah ini berfungsi sebagai sumber energi dan karbon bagi aktivitas mikroorganisme anaerobic yang terdapat dalam fermentor. Pembuatan Ekoensim membutuhkan air sebagai media fermentasi. Pembuatan EkoEnsim membutuhkan komposisi bahan berbasis \% berat dengan perbandingan 1 bagian gula: 10 bagian bahan baku dan 10 bagian air (Gambar 3).

Tahapan pembuatan ekoensim adalah sebagai berikut. Pertama, bahan baku dicacah untuk memperluas permukaannya sehingga cepat terdekomposisi. Kedua, siapkan air sebagai media fermentasi. Ketiga gula merah dilarutkan lebih dulu. Semua bahan yang telah dicampur merata dalam suatu wadah, kemudian dipidahkan ke fermentor (toples plastic). Pengisian campuran bahan ke dalam fermentor kurang lebih setengah dari ukuran fementor. Selanjutnya fermentor ditutup rapat, diberi tanggal pembuatan Eko-Ensim dan disimpan selama 3 bulan untuk proses fermentasi. Bagian Eko-Ensim yang dipanen adalah cairan Eko-Ensim. Ampas ekoensim dapat digunakan sebagai pupuk organic padat. Rangkain buatan Eko-Ensim pada kegiatan Bimtek di kelompok PaManSam ditunjukan dalam Gambar 4.

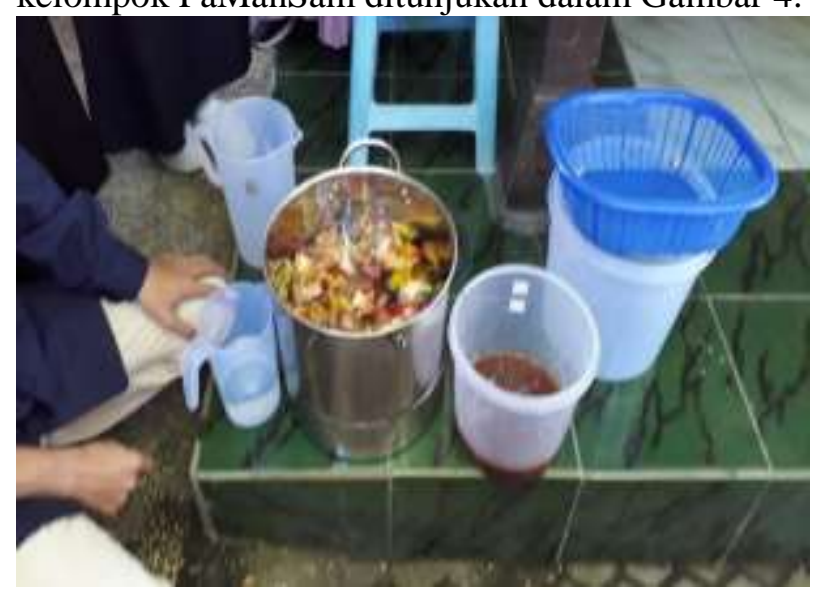

Gambar 3. Bahan yang diperlukan untuk pembuatan Eko-Ensim. 


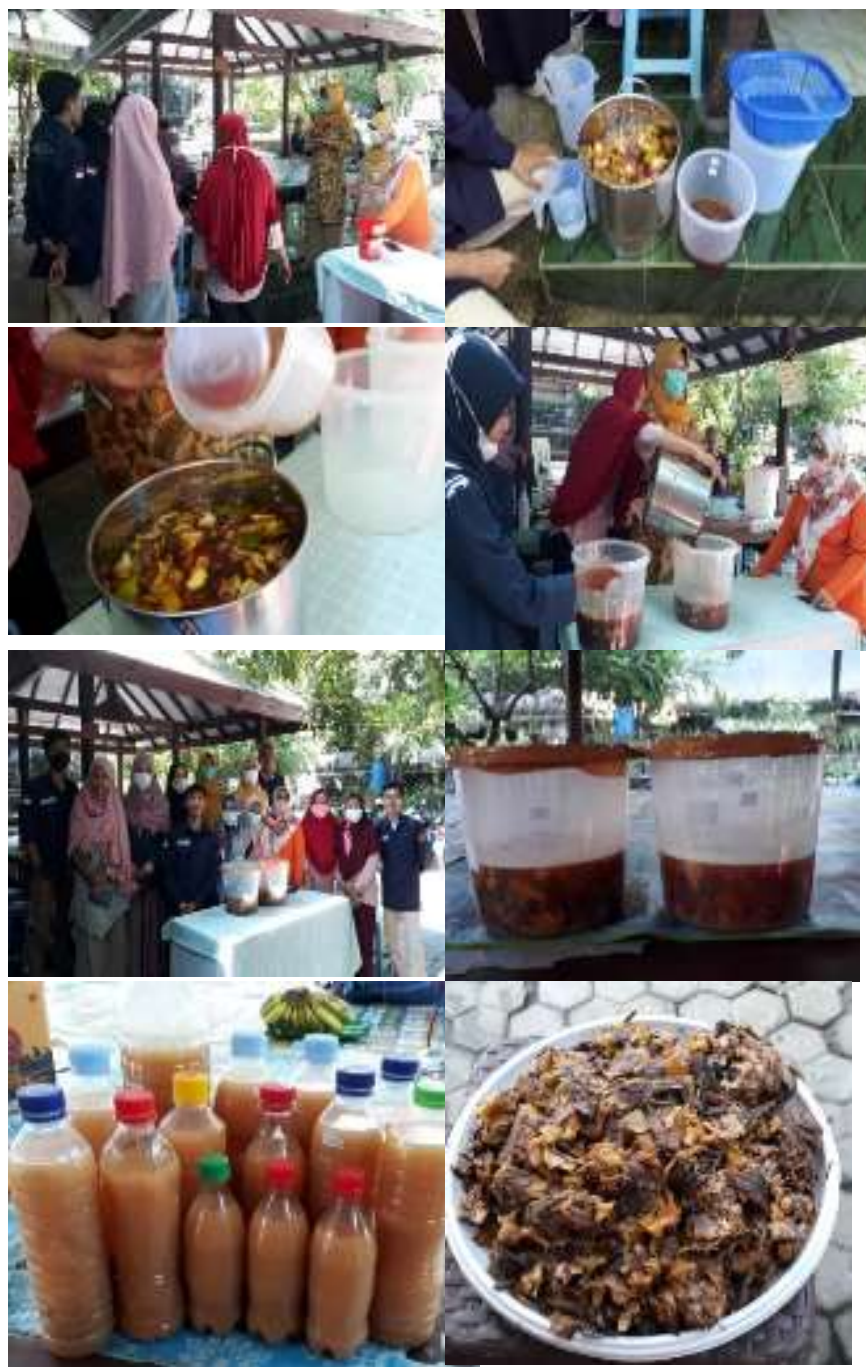

Gambar 4. Proses pembuatan Eko-Ensim.

A. penjelasan tentang Eko-Ensim;

B. Pengenalan bahan baku Ek0-Ensim;

C. Pencampuran bahan Eko-Ensim;

D. Penungangan campuran pada wadah fermentasi;

E Fermentasi Eko-Ensim;

F Foto Bersama;

G.Produk Eko Ensim (cairan dan Ampas Eko Ensim)

Kegunaan ekoenzim sangat banyak, diantaranya sebagai disinfektan, dengan perbandingan Eko Enzim: air $=1 \mathrm{ml}$ (1 takaran seperti tutup botol) : $1000 \mathrm{ml}$. Sebagai pupuk organic cair tanaman, komposisinya bervariasi tergantung pada jenis tanaman dan umur tanaman yang akan dipupuk. Contoh untuk pupuk tanaman bunga dibutuhkan komposisi $20 \mathrm{ml}$ Eko Ensim dalam $1000 \mathrm{ml}$ air, untuk tanaman berbatang kuat (seperti terong) komposisi $30 \mathrm{ml}$ dalam $1000 \mathrm{ml}$ air. Demikian juga untuk tanaman jahe. Pemberian dilakukan setiap 10 hari sekali selama masa pertumbuhan tanaman dengan volume $5 \mathrm{sd} 10 \mathrm{ml}$ per kali pemberian. Pertumbuhan tanaman yang diberi pupuk cair Eko-Ensim ditunjukan pada Gambar 5

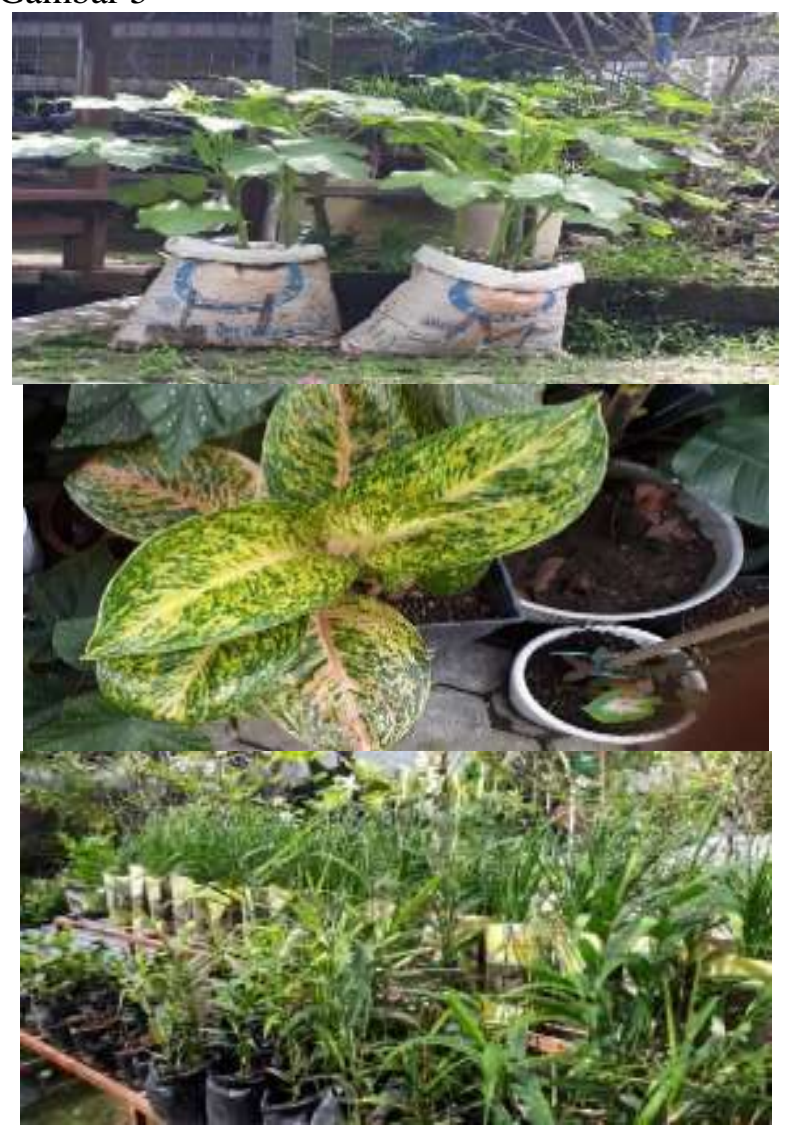

Gambar 5. Tanaman yang diberi pupuk cair organic produk Eko-Ensim

\section{Evaluasi Kegiatan}

Kegiatan penyuluhan telah mampu meningkatkan pengetahuan pesrta penyuluhan Hal ini ditunjukan dengan adanya perubahan nilai antara pre dan pos tes. Sebelum kegiatan peyuluhan, nilai rata-rata ujian peserta adalah $65 \pm 6,0$ (rerata \pm standart error), sedangkan nilai setelah penyuluhan adalah 79,50 \pm 7,0 (rerata \pm standart error). Dari analisis statistic dengan menggunakan standart error menunjukan adanya perbedaan yang nyata antar nilai pre dan pos test. Hasil ini menunjukkan bahwa kegiatan penyuluhan telah mampu meningkatkan pengetahuan peserta penyuluhan. Dengan kata lain kegiatan penyuluhan 
berhasil memberikan pemahaman tentang pengolahan sampah kepada peserta penyuluhan.

Kaitan dengan pembuatan Bimtek EkoEnsim, peserta kegiatan sangat tertarik karena caranya mudah dan bahannya tersedia disetiap saat serta bermanfaat untuk mengurangi timbunan sampah. Peserta Bimtek telah juga mengaplikasikan Eko-Ensim sebagai pupuk organic cair pada tanaman terong, bunga dan jahe. Peserta Bimtek tertarik untuk mengembangkan pembuatan Eko Ensim untuk tujuan pembuatan handsanitazer ataupun produk lainnya. Dari kegiatan ini peserta penyuluhan termotivasi untuk membagun kelompok tani mellinial sebagai bagian dari kelompok PaManSam.

\section{Kesimpulan}

1. Peserta penyuluhan menjadi mengetahui bahwa kegiatan pengelolaan sampah diatur dalam Undang-Undang RI no 18 tahun 2008 dan untuk provensi NTB diatur dalam Perda Prov. NTB no5 tahun 2019.

2. Peserta penyuluhan mengetahui cara pengelolaan sampah organic yang ramah lingkungan dengan membuat Eko-Ensim.

3. Peserta penyuluhan menguasai teknik pembuatan Eko-Ensim dan pemanfaatannya sebagai pupuk organic cair pada tanaman.

4. Pengetahuan masyarakat tentang pembuatan Eko-Ensim dapat membuka wawasan peserta penyuluhan untuk menghasilkan produk sejenis dengan berbasiskan pada proses fermentasi bahan organic yang mudah didekomposisi.

\section{Daftar Pustaka}

Astuti, A. P., \& Maharani, E. T. W. (2020). PERBANDINGAN ORGANOLEPTIK PADA DELAPAN VARIABEL PRODUK EKOENZIM. EDUSAINTEK, 4.

Dewi, D. M. (2021). Pelatihan Pembuatan Eco Enzyme Bersama Komunitas Eco Enzyme Lambung Mangkurat Kalimantan Selatan. Jurnal Pengabdian ILUNG (Inovasi Lahan Basah Unggul), 1(1), 67-76.

Larasati, D., Astuti, A. P., \& Maharani, E. T. W. (2020). Uji Organoleptik Produk EcoEnzyme dari Limbah Kulit Buah (Studi
Kasus di Kota Semarang). EDUSAINTEK, 4.

Moerad, S. K. (2012). Peran serta Masyarakat Pemulung dalam Pengelolaan Lingkungan Binaan di TPA Benowo Surabaya. NUANSA: Jurnal Penelitian Ilmu Sosial Dan Keagamaan Islam, 9(2).

Nur, T., Noor, A. R., \& Elma, M. (2016). Pembuatan pupuk organik cair dari sampah organik rumah tangga dengan bioaktivator EM4 (Effective microorganisms). Konversi, 5(2), 44-51.

Putri, R. F. (2018). Pelatihan pemanfaatan barang bekas menjadi barang yang bernilai ekonomi. Amaliah: Jurnal Pengabdian Kepada Masyarakat, 2(1), 150-155.

Susilowati, L. E., Arifin, Z., \& Kusumo, B. H. (2021). PENGOMPOSAN SAMPAH ORGANIK RUMAH TANGGA DENGAN DEKOMPOSER LOKAL DI DESA NARMADA, KABUPATEN LOMBOK BARAT. JMM (Jurnal Masyarakat Mandiri), 5(1), 34-45.

Utami, M. M. I. P., Astuti, A. P., \& Maharani, E. T. W. (2020). MANFAAT EKOENZIM DARI LIMBAH ORGANIK RUMAH TANGGA SEBAGAI PENGAWET BUAH TOMAT CHERRY. EDUSAINTEK, 4.

Yanti, R. N., Lestari, I., \& Ikhsani, H. (2021). IbM Membuat Eco Enzym dengan Memanfaatkan Limbah Organik Rumah Tangga di Bank Sampah Berkah Abadi Kelurahan Limbungan Kecamatan Rumbai Timur. SNPKM: Seminar Nasional Pengabdian Kepada Masyarakat, 3, 8-13. 